\title{
EVALUATION OF THE EFFECTS OF EPHEDRINE ON HUMAN LYMPHOCYTES IN THE COMET
} ASSAY

\author{
RADAKOVIĆ MILENA*, DJELIĆ N*, STANIMIROVIĆ Z*, PLEĆAŠ-SOLAROVIĆ BOSILJKA**, \\ SPREMO-POTPAREVIĆ BILJANA**, ŽIVKOVIĆ LADA** and BAJIĆ $\mathrm{V}^{* * *}$ \\ *University of Belgrade, Faculty of Veterinary Medicine, Serbia \\ **University of Belgrade, Faculty of Pharmacy, Serbia \\ ***Institute of Research and Development, Galenika, Belgrade, Serbia

\section{(Received 11 th $^{\text {th }}$ October 2010)}

Ephedrine, a natural alkaloid from plants of the genus Ephedra, has a chemical structure similar to catecholamines. It is well established that catecholamines (adraneline, noradrenaline and dopamine) cause genotoxic and mutagenic effects. Therefore, the objectives of this investigation were to examine weather ephedrine can exhibit genotoxic effects on isolated human lymphocytes in the Comet assay. Dose-response of human lymphocytes was determined at the concentration range of ephedrine from $0.0005 \mu \mathrm{M}$ to $500 \mu \mathrm{M}$. Three concentrations of ephedrine $(1,50$ and $300 \mu \mathrm{M})$ which had acceptable cell viability (over $90 \%$ ) were used for further experiments with inhibitors of DNA reparation (cytosine arabinoside and hydroxyurea). The obtained results showed that ephedrine did not induce DNA damage in isolated human lymphocytes. However, co-treatment of the negative control with DNA repair inhibitors caused a slight but significant increase of DNA damage, due to an endogenous DNA damage. Interestingly, cells treated with ephedrine and DNA repair inhibitors did not express increased DNA damage. On the basis of the obtained results it can be concluded that ephedrine did not exhibit genotoxic effects on isolated human lymphocytes. This result is in accordance with previous investigations showing negative genotoxicological results for ephedrine using bacterial gene mutation test-systems and in vitro cytogenetic analysis.

Key words: Comet assay, DNA damage, DNA repair inhibitors, ephedrine

\section{INTRODUCTION}

Ephedrine is an alkaloid derived from various plants of the genus Ephedra. The herb Ephedra sinica contains ephedrine and pseudoephedrine as its principal active compounds. In traditional Chinese medicine, ephedrine has been used in the treatment of asthma, bronchitis, nose and lung congestion and fever 
with anhydrosis for centuries (Ford et al., 2001). Both ephedrine and pseudoephedrine act as a bronchodilatator and increase blood pressure, but pseudoephedrine has considerably less effect (Drew et al., 1978).

Except for being used as a nasal decongestant (Ma et al., 2007), ephedrine is also used in thermogenic weight loss pills which contain a combination of ephedrine, caffeine and aspirin. This dietary supplement combination is also taken by body builders before workouts (Greenway and Bray, 2008; Zheng et al., 2009).

In veterinary medicine ephedrine may be used to help control urinary incontinence in dogs and cats (Carofiglio et al., 2006). It may also be used to open up the air passages of the lungs and to relieve nasal congestion (Koss et al., 2002).

Ephedrine is an indirectly acting sympathomimetic amine, which acts mainly by stimulating noradrenaline release from presynaptic terminals and thereby stimulating the postsynaptic adrenergic receptors. Ephedrine probably does not interact directly with $\alpha$ receptors (Ma et al., 2007), but it can stimulate $\beta$ receptors (Vansal and Feller, 1999).

There are some controversies about the safety of ephedra use. Indiscriminate consumption of ephedrine-type alkaloids has resulted in more than 1000 reported cases of poisoning and other serious effects, some of which were fatal, in the period 1993-2000. in the USA (FDA, 2000). The most serious side effects of ephedrine overdose include hypertension, heart palpitations, psychosis, tremors, myocardial infarction, seizures and stroke. Other signs of ephedrine abuse include nerve damage, muscle injury, memory loss and insomnia.

Despite numerous data concerning toxic effects of ephedrine, there is only limited information about possible genotoxic effects of ephedrine. Ephedrine has not exhibited genotoxic effects in bacterial gene mutation assays and in vitro cytogenetic studies (Brambilla and Martelli, 2009). However, to our knowledge, genotoxic effects of ephedrine were not evaluated using single cell gel electrophoresis (Comet) assay. Since the Comet assay is a very sensitive method for detection of DNA damage, the objective of this investigation was to evaluate the effects on isolated human lymphocytes using the in vitro Comet assay. For the sake of comparison, we chose human lymphocytes instead of animal lymphocytes because most of the in vitro genotoxicological studies on hormones were performed on human lymphocytes.

Moreover, there are some literature data that various catecholamines (adrenaline, noradrenaline and dopamine) may exhibit genotoxic and mutagenic effects (Moldeus et al., 1983; Djelić and Anderson, 2003). Since ephedrine has a similar chemical structure to catecholamines we wanted to examine whether ephedrine can induce DNA damage. Otherwise, the catechol group may be considered necessary for genotoxic effects. 


\section{MATERIALS AND METHODS}

\section{Blood samples and treatment}

In these experiments we used peripheral venous blood from three healthy volunteers, less than 25 years of age. Heparinized blood samples (sodium heparine, Galenika, Belgrade, Serbia) were immediately processed for isolation of lymphocytes on ficol gradient. The $50 \mu \mathrm{L}$ of lymphocyte suspension was incubated in PBS solution containing ephedrine hydrochloride (CAS No 50-98-6, Sigma, St. Louis, MO) at concentrations in a range from $0.0005 \mu \mathrm{M}$ to $500 \mu \mathrm{M}$. The negative control was PBS, which is the solvent for ephedrine. The positive control was $100 \mu \mathrm{M}$ aqueous solution of $\mathrm{H}_{2} \mathrm{O}_{2}$. Lymphocytes were incubated at $37^{\circ} \mathrm{C}$ for $1 \mathrm{~h}$. The study was approved by the local Medical Ethics Committee, performed in accordance with the Declaration of Helsinki, and informed donor consent was also obtained.

\section{Comet assay}

Before each experiment, microscope slides were precoated with $1 \%$ normal agarose (Sigma, St. Louis, MO) in double distilled water and left at room temperature to allow agarose to dry. The alkaline single cell gel electrophoresis (Comet) assay was performed on isolated human peripheral blood lymphocytes. Lymphocytes were isolated using Amersham ficol gradient as described elsewhere (Soltani et al., 2008). The cell suspension in PBS was treated with ephedrine at concentrations $0.0005 \mu \mathrm{M}, 0.001 \mu \mathrm{M}, 0.01 \mu \mathrm{M}, 0.2 \mu \mathrm{M}, 1 \mu \mathrm{M}, 5 \mu \mathrm{M}$, $50 \mu \mathrm{M}, 150 \mu \mathrm{M}, 350 \mu \mathrm{M}$ and $500 \mu \mathrm{M}$ for one hour at $37^{\circ} \mathrm{C}$. After the treatment, cell suspensions were centrifugated at $2000 \mathrm{rpm}$ for $5 \mathrm{~min}$, and the cell pellet was mixed with an equal amount of low melting point agarose (Sigma), rapidly placed on precoated microscopic slides covered with a cover-slip and allowed to solidify for $5 \mathrm{~min}$ at $4^{\circ} \mathrm{C}$. Then the coverslips were gently removed, and the $1 \%$ agarose was placed, covered with a coverslip, left for 5 min at $4^{\circ} \mathrm{C}$, then the coverslip was removed and the slides were placed overnight in a lysis solution $(2.5 \mathrm{M} \mathrm{NaCl}$, $100 \mathrm{mM}$ EDTA, $10 \mathrm{mM}$ Tris, 1\% Triton X100 and 10\% DMSO, pH 10 adjusted with $\mathrm{NaOH})$. After lysis, the slides were placed in electrophoresis buffer $(10 \mathrm{M} \mathrm{NaOH}$, $200 \mathrm{mM}$ EDTA, pH 13) for $30 \mathrm{~min}$. at $4^{\circ} \mathrm{C}$ in the dark to allow DNA unwinding. Electrophoresis was carried out for $30 \mathrm{~min}$. at $25 \mathrm{~V}$ and $300 \mathrm{~mA}$. Finally, the slides were gently rinsed with a neutralising solution $(0.4 \mathrm{M}$ Tris base, $\mathrm{pH} 7.5)$ three times, 5 min each time. Staining of DNA was accomplished with $50 \mu \mathrm{L}$ of ethidium bromide $(20 \mu \mathrm{g} / \mathrm{mL})$ per each slide. The comets were observed and analysed using Olympus X 50 microscope (Olympus Optical Co., Gmbh Hamburg, Germany), equipped with a device for fluorescence recording at $100 \times$ magnification. Evaluation of DNA damage was performed as described by Anderson et al. (1994). Namely, cells were graded by eye into five categories corresponding to the following amounts of DNA in the tail: $(A)$ no damage, $<5 \%$; (B) low level damage, 5-20\%; (C) medium level damage, 20-40\%; (D) high level damage, 40-95\%; (E) total damage, >95\% (Fig. 1).

In order to obtain semi-quantitative analysis of data, the score of DNA damage (the migration of DNA) was calculated as follows: $2 \times B+3 \times C+4 \times D+$ 
$5 \times E$, where $B$ to $E$ represents percentages of cells within the above mentioned categories $\mathrm{B}$ to $\mathrm{E}$.

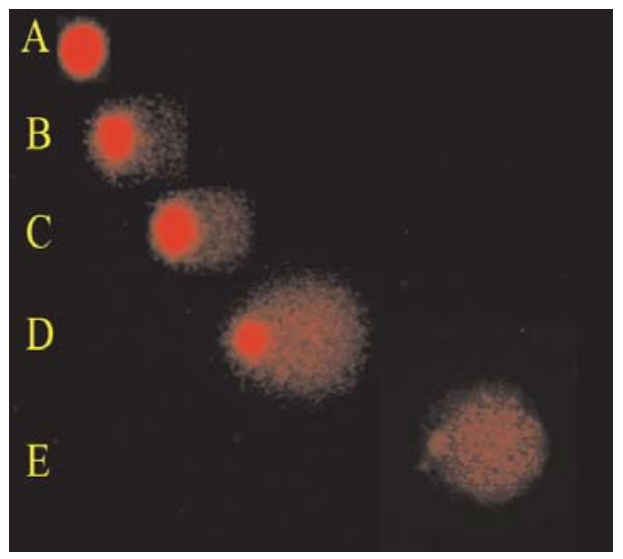

Figure 1. Five classes of comets: (A) no damage, $<5 \%$; (B) low level damage, 5-20\%; (C) medium level damage, 20-40\%; (D) high level damage, 40-95\%; (E) total damage, $>95 \%$

\section{Statistical analysis}

Data from the Comet assay were evaluated by the non-parametric KruskalWallis ANOVA followed by the Dunn's multiple comparison test. A $P$-value of $\leq 0.05$ was considered as indicative of statistical significance.

\section{RESULTS}

DNA damage analysis of a wide range of ephedrine concentrations is presented in Fig. 2. In this investigation, we evaluated the effects of a broad spectrum of ephedrine concentrations (range from $0.0005 \mu \mathrm{M}$ to $500 \mu \mathrm{M}$ ). However, we did not observe significant changes of the DNA migration in the Comet assay and the cytotoxicity was acceptable (lower than 10\%). Thus, percentage of cells without DNA damage was in a range from $72 \%$ to $89.5 \%$ in vials treated with various concentrations of ephedrine. As for the negative control (PBS), there was $91 \%$ of cells without DNA damage (estimated less than $5 \%$ of damaged DNA). Only the positive control $\left(100 \mu \mathrm{M} \mathrm{H}_{2} \mathrm{O}_{2}\right)$ gave a significant rise in DNA damage, so there was only $32 \%$ of undamaged cells. Moreover, the distribution of DNA damage in cells treated with $100 \mu \mathrm{M} \mathrm{H}_{2} \mathrm{O}_{2}$ clearly showed an increase of the percentage of DNA damage for each of the four categories (B to $E$ ).

In order to evaluate the possible changes of DNA damage under the influence of DNA repair inhibitors we carried out two separate experiments with cytosine arabinoside (AraC) and hydrohyurea (HU). Namely, in the first experiment (Fig. 3) we tested three concentrations of ephedrine (1, 50 and $300 \mu \mathrm{M})$ without reparation inhibitors, and the same concentrations with 
reparation inhibitors $(20 \mu \mathrm{M}$ of AraC $+2000 \mu \mathrm{M} \mathrm{HU})$. The percentage of undamaged cells was slightly lower in vials with reparation inhibitors, but it did not reach statistical significance. In the second experiment (Fig. 4) we used the same concentrations of ephedrine, but concentrations of reparation inhibitors were higher $(40 \mu \mathrm{M}$ of AraC $+4000 \mu \mathrm{M} \mathrm{HU})$. The obtained results were similar to the first experiment - lower, but unsignificant percentage of undamaged cells. Only the co-treatment of the negative control with higher concentations of inhibitors of

\begin{tabular}{|c|c|c|}
\hline $\begin{array}{c}\% \text { of cells } \\
\text { concetrations }(\mu \mathrm{M})\end{array}$ & $\begin{array}{l}\text { 口total } \\
\text { \$ high } \\
\text { I medium } \\
\text { इ low } \\
\text { - none }\end{array}$ & $\begin{array}{l}1 \text { - negative control } \\
2 \text { - Ephedrine } 0.0005 \mu \mathrm{M} \\
3 \text { - Ephedrine } 0.001 \mu \mathrm{M} \\
\text { 4- Ephedrine } 0.01 \mu \mathrm{M} \\
5 \text { - Ephedrine } 0.2 \mu \mathrm{M} \\
6 \text { - Ephedrine } 1 \mu \mathrm{M} \\
7 \text { - Ephedrine } 5 \mu \mathrm{M} \\
8 \text { - Ephedrine } 50 \mu \mathrm{M} \\
9 \text { - Ephedrine } 150 \mu \mathrm{M} \\
10 \text { - Ephedrine } 300 \mu \mathrm{M} \\
11 \text { - Ephedrine } 500 \mu \mathrm{M} \\
12-100 \mu \mathrm{M} \mathrm{H}_{2} \mathrm{O}_{2}\end{array}$ \\
\hline
\end{tabular}

Figure 2. Dose-response analysis of the effects of ephedrine on isolated human lymphocytes. Only the positive control caused significant increase of DNA migration. $\star \star \star p<0.001$

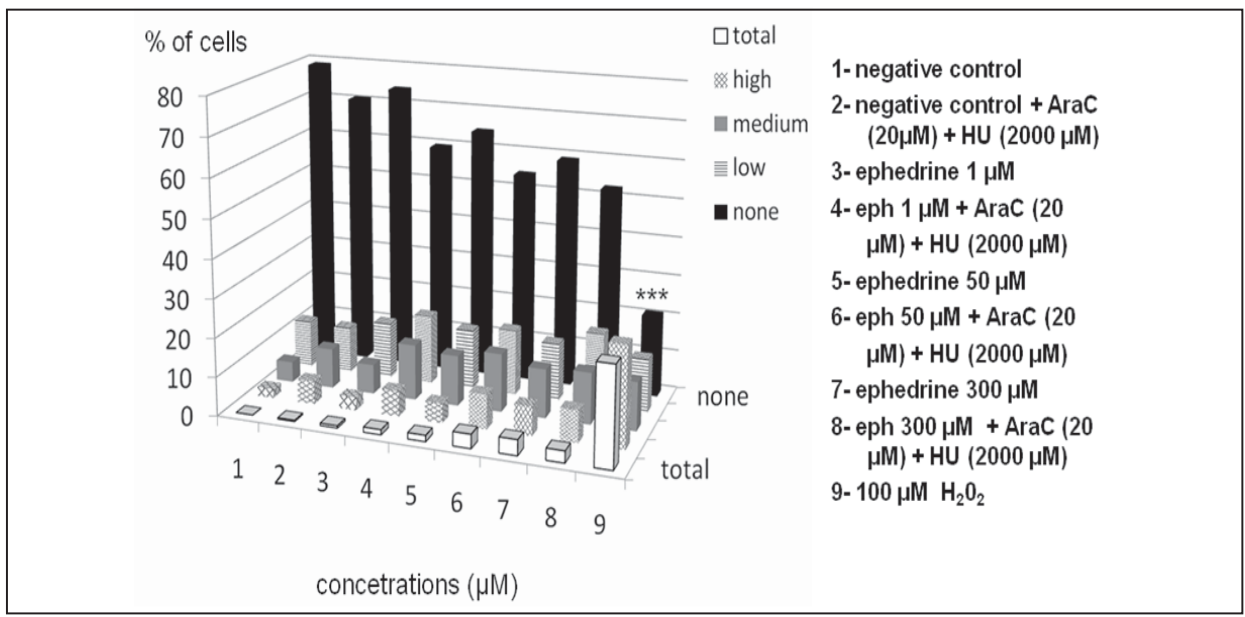

Figure 3. Analysis of DNA damage in isolated human peripheral blood lymphocytes simultaneously treated with ephedrine and DNA repair inhibitors (20 $\mu \mathrm{M}$ cytosine arabinoside and $2000 \mu \mathrm{M}$ hydrohyurea). ${ }^{\star *} \mathrm{p}<0.001$ 
reparation produced a slight, but statistically significant rise in DNA damage. Interestingly, DNA damage in the negative control co-treated with reparation inhibitors did not differ significantly from damage in cells treated with ephedrine and reparation inhibitors.

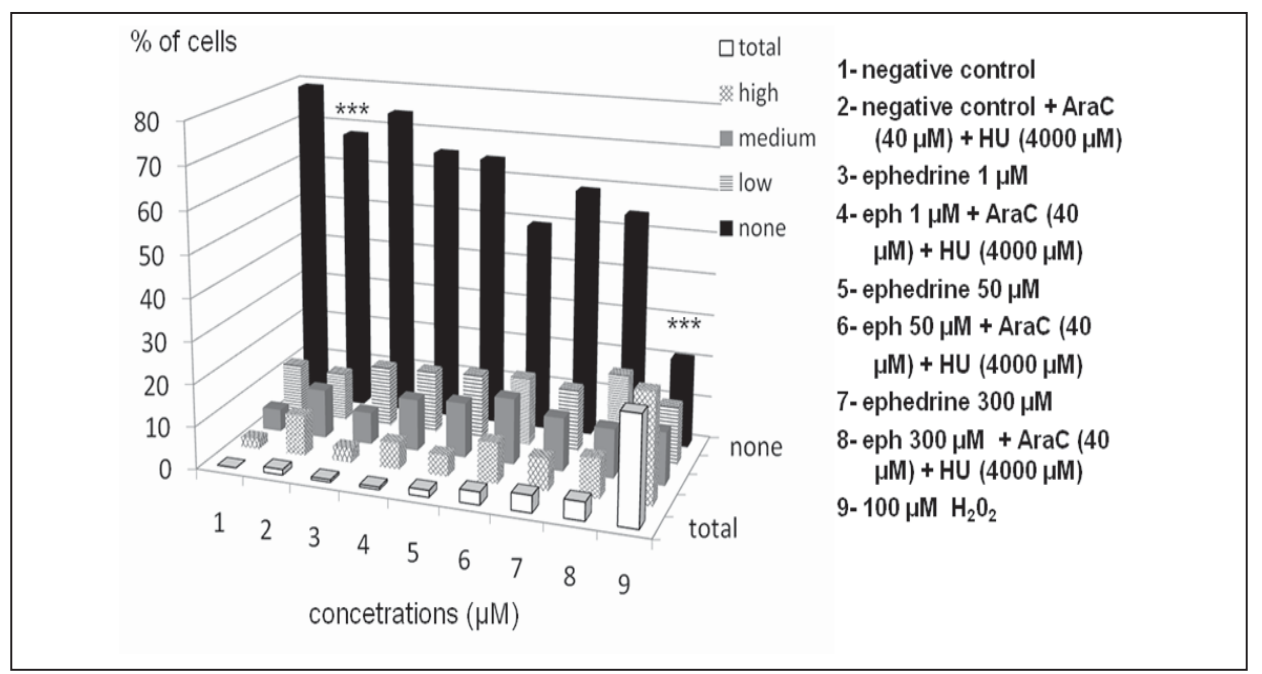

Figure 4. Analysis of DNA damage in isolated human peripheral blood lymphocytes simultaneously treated with ephedrine and DNA repair inhibitors (40 $\mu \mathrm{M}$ cytosine arabinoside and $4000 \mu \mathrm{M}$ hydrohyurea). Samples treated with AraC and HU only had significantly higher DNA damage compared to the negative control without AraC and $\mathrm{HU}$, due to an endogenous DNA damage. Positive control caused significantly higher DNA damage in comparison to all other experimantal points. ${ }^{\star *} p<0.001$

\section{DISCUSSION}

Ephedrine has a similar chemical structure to catecholamines. There are experimental findings showing that catecholamines (adrenaline, noradrenaline and dopamine) may exhibit genotoxic effects in various test-systems (Moldeus et al., 1983; McGregor et al., 1988; Miura et al., 2000; Djelić and Anderson, 2003; Dobrzynska et al., 2004). Therefore, the main idea of this investigation was to evaluate possible genotoxic effect of ephedrine and compare it with effects of catecholamines.

A broad spectrum of concentrations of ephedrine (range from $0.0005 \mu \mathrm{M}$ to $500 \mu \mathrm{M})$ was investigated in the in vitro Comet assay on isolated human lymphocytes. At all applied concentrations, ephedrine has caused less than $10 \%$ of cytotoxicity evaluated by Trypan blue exclusion assay, so the conditions in the Comet assay were appropriate for detection of DNA damage. Lymphocytes treated with ephedrine alone, did not express increased DNA damage in comparison to the negative control. However, co-treatment of the negative control with higher concentrations of DNA repair inhibitors (40 $\mu \mathrm{M}$ AraC $+4000 \mu \mathrm{M} \mathrm{HU})$ 
caused a slight, but significant increase of DNA damage. Possibly, an increase of DNA damage of human lymphocytes co-treated with AraC $+\mathrm{HU}$ results from unrepaired endogenous DNA damage. Therefore, it can be concluded that ephedrine does not induce DNA damage in isolated human lymphocytes.

Absence of genotoxic effects of ephedrine obtained in the present study is in accordance with results of several studies on ephedrine genotoxicity in various test systems. Thus, ephedrine has not exhibited genotoxic effects in Salmonella mutagenicity tests (Zeiger et al., 1988). In addition, ephedrine did not induce chromosome aberrations in vitro (Hilliard et al., 1998).

Bearing in mind that various catecholamines exhibit genotoxic effects, it seems that the catechol group is necessary for these effects. Namely, although ephedrine has a similar chemical structure to catecholamines, it lacks hydroxyl groups in the phenolic ring, so it does not posses the catechol moiety. There is experimental evidence that aromatic catechol groups are necessary for signal transduction after binding of catecholamines to specific membrane receptors (Liapakis et al., 2004). However, catechol moieties can be also involved in redox cycling under the influence of superoxide anion and, therefore, may induce oxidative stress (Genova et al., 2006). Some indirect experimental data corroborate the idea that DNA damage induced by catecholamines mainly results from reactive oxygen species (ROS). Namely, the antioxidant catalase significanly reduces DNA damaging effects of noradrenaline in the Comet assay on human lymphocytes (Djelić and Anderson, 2003) and sperm (Dobrzynska et al., 2004). Therefore, we assume that ephedrine has not expressed genotoxic effects not only in this study, but also in other test-systems probably because it contains the phenolic moiety instead of the catechol moiety which is present in catecholamines.

It should be mentioned, however, that in some test-systems, such as in vitro cytogenetic test, adrenaline does not exhibit genotoxic effects (Djelić et al., 2003). Among other hormones which can induce ROS, the contradictory results of genotoxicity evaluation are also observed for oestradiol (Djelić et al., 2006) and thyroxine (Djelić et al., 2007).

In conclusion, although the use of ephedrine can produce serious pharmacological side-effects sometimes including a fatal outcome, it seems that short-term exposure to ephedrine do not induce genotoxic effects. Bearing in mind previous and present studyes on ephedrine genotoxicity, probably there is no genetic risk from Ephedra use in medicine.

\section{ACKNOWLEDGMENT:}

This investigation was supported by Ministry of Science and Technological Development, grant No Ol173034.

Address for correspondence:

Dr. Ninoslav Djelić, Professor

Department of Biology

Faculty of Veterinary Medicine

University of Belgrade

Bul. oslobodjenja 18

11000 Belgrade, Serbia

E-mail: ndjelic@vet.bg.ac.rs 


\section{REFERENCES}

1. Anderson D, Yu T-W, Phillips BJ, Schmezer P, 1994, The effect of various antioxidants and other modifying agents on oxygen-radical-generated DNA damage in human lymphocytes in the COMET assay, Mutat Res 307, 261-71.

2. Brambilla G, Martelli A, 2009, Update on genotoxicity and carcinogenicity testing of 472 marketed pharmaceuticals, Mutat Res, 681, 209-29.

3. Carofiglio F, Hamaide AJ, Farnir F, Balligand MH, Verstegen JP, 2006, Evaluation of the urodynamic and hemodynamic effects of orally administered phenylpropanolamine and ephedrine in female dogs, Am J Vet Res, 67, 723-30.

4. Djelić N, Djelić D, Spremo-Potparević B, Marković B, Živković L, 2003, Cytogenetic analysis of the effects of epinephrine on cultured human lymphocytes, Acta Vet (Beograd), 53, 2, 113-20.

5. Djelić N, Nešić I, Stanimirović Z, Jovanović S, 2007, Evaluation of the genotoxic effects of thyroxine using in vivo cytogenetic test on Swiss albino mice, Acta Vet (Beograd), 57, 5-6, 487-95.

6. Djelić N, Spremo-Potparević B, Marković B, Živković L, Djelić D, 2006, Cell cycle kinetics and cytogenetic changes in human lymphocytes exposed to oestradiol in vitro, Acta Vet (Beograd), $56,1,37-48$.

7. Djelić N, Anderson D, 2003, The effect of the antioxidant catalase on oestrogens, triiodothyronine, and noradrenaline in the Comet assay, Teratog Carcinog Mutagen, 23, 69-81.

8. Dobrzynska MM, Baumgartner A, Anderson D, 2004, Antioxidants modulate thyroid hormone- and noradrenaline-induced DNA damage in human sperm, Mutagenesis 19, 325-30.

9. Drew CD, Knight GT, Hughes DT, Bush M, 1978, Comparison of the effects of D-(-)ephedrine and L$(+)$-pseudoephedrine on the cardiovascular and respiratory systems in man, $\mathrm{Br} J \mathrm{Clin}$ Pharmacol, 6, 221-5.

10. Food and Drug Administration, 2000, Assessment of Public Health Risks Associated with the use of ephedrine alkaloid-containing dietary suplements.

11. Ford MD, Delaney KA, Ling LJ, Erickson $T$ (Eds.), 2001, Clinical Toxicology, WB Saunders, Philadelphia, USA

12. Genova ML, Abd-Elsalam NM, Madhy el SME, Bernacchia A, Lucarini M, Pedulli GF et al., 2006, Redox cycling of adrenaline and adrenochrome catalysed by mitochondrial complex I, Arch Biochem Biophys, 447, 167-73.

13. Greenway FL, Bray GA, 2008, Treatment of hypothalamic obesity with caffeine and ephedrine, Endocr Pract, 14, 697-703.

14. Hilliard CA, Armstrong MJ, Bradt CI, Hill RB, Greenwood SK, Galloway SM, 1998, Chromosome aberrations in vitro related to cytotoxicity of nonmutagenic chemicals and metabolic poisons, Environ Mol Mutagen, 31, 316-26.

15. Koss MC, Yu Y, Hey JA, McLeod RL, 2002, Acustic rhinometry in the dog: a novel large animal model for studies of nasal congestion, Am J Rhinol, 16, 49-55.

16. Liapakis G, Chang WC, Papadokostaki M, Javitch JA, 2004, Synergistic contribution of the functional groups of epinephrine to its affinity and efficacy at the $\beta_{2}$ adrenergic receptor, $\mathrm{Mol}$ Pharmacol, 65, 1181-90.

17. Ma G, Bavadekar SA, Davis YM, Lalchandani SG, Nagmani R, Schaneberg BT et al., 2007, Pharmacological effects of ephedrine alkaloids on human $\alpha_{1}$ and $\alpha_{2}$-adrenergic receptor subtypes, J Pharmacol Exp Ther, 322, 214-21.

18. McGregor D, Raich CG, Brown A, Edwards I, Reynolds D, West $K$ et al., 1988, Reactivity of catecholamines and related substances in the mouse lymphoma L5178Y cell assay for mutagens, Environ Mol Mutagen, 11, 523-44.

19. Miura T, Muraoka S, Fujimoto Y, Zhao K, 2000, DNA damage induced by catechol derivatives, Chem Biol Interact, 126, 125-36.

20. Moldeus P, Nordenskjold M, Bolcsfoldi G, Eiche A, Haglund U, Lambert B, 1983, Genetic toxicity of dopamine, Mutat Res, 124, 9-24. 
21. Soltani F, Mosaffa F, Iranshahi M, Karimi G, Malekaneh M, Haghighi F et al., 2008. Evaluation of antigenotoxicity effects of umbelliprenin on human peripheral lymphocytes exposed to oxidative stress, Cell Biol Toxicol, 25, 291-6.

22. Vansal SS, Feller DR, 1999, Direct effects of ephedrine isomers on human $\beta$-adrenergic receptor subtypes, Mol Cell Pharmacol, 58, 807-10.

23. Zeiger E, Anderson B, Haworth S, Lawlor T, Mortelmans K, 1988, Salmonella mutagenicity tests. IV. Results from testing of 300 chemicals, Environ Mol Mutagen, 11 (Suppl 12), 1-158.

24. Zheng J, DiLorenzo DJ, McLaughlin L, Roberts AT, Greenway FL, 2009, Stimulation of sympathetic innervation in the upper gastrointestinal tract as a treatment for obesity, Med Hypotheses, 72 , 706-10.

\section{EVALUACIJA DEJSTVA EFEDRINA NA LIMFOCITE ČOVEKA U KOMET TESTU}

\section{RADAKOVIĆ MILENA, DJELIĆ N, STANIMIROVIĆ Z, PLEĆAŠ-SOLAROVIĆ BOSILJKA, SPREMO-POTPAREVIĆ BILJANA, ŽIVKOVIĆ LADA i BAJIĆ V}

\section{SADRŽAJ}

Efedrin, prirodni alkaloid iz biljaka roda Ephedra, ima sličnu hemijsku strukturu sa kateholaminima. Dobro je poznato da kateholamini (adrenalin, noradrenalin i dopamin) mogu da prouzrokuju genotoksične i mutagene efekte. Stoga su ciljevi ovog istraživanja bili da se ispita da li efedrin može da ispolji genotoksične efekte na izolovanim limfocitima čoveka u Komet testu. Odnos doza-efekat određen je u rasponu koncentracija efedrina od $0.0005 \mu \mathrm{M}$ do $500 \mu \mathrm{M}$. Tri koncentracije efedrina (1, 50 and $300 \mu \mathrm{M})$ koje su imale prihvatljiv nivo ćelijske vijabilnosti (preko 90\%) upotrebljene su za dalje eksperimente sa inhibitorima reparacije DNK (citozin arabinozid i hidroksiurea). Dobijeni rezultati pokazuju da efedrin nije indukovao oštećenja DNK na izolovanim limfocitima čoveka. Međutim, istovremeni tretman sa inhibitorima reparacije DNK doveo je do malog ali statistički značajnog porasta oštećenja DNK kod negativne kontrole, usled endogenog oštećenja DNK. Interestantno je da ćelije tretirane sa efedrinom i inhibitorima reparacije DNK nisu ispoljile povećan nivo oštećenja DNK. Na osnovu dobijenih rezultata može se zaključiti da efedrin nije ispoljio genotoksične efekte na izolovanim limfocitima čoveka. Ovaj rezultat je u saglasnosti sa prethodnim istraživanjima u kojima je dokazano da efedrin ne dovodi do genotoksičnih efekata u bakterijskim testovima na genske mutacije i u in vitro citogenetičkim analizama. 
